\title{
Use of T-PODs for acoustic monitoring of Cephalorhynchus dolphins: a case study with Hector's dolphins in a marine protected area
}

\author{
William Rayment ${ }^{1, *}$, Steve Dawson ${ }^{1}$, Liz Slooten $^{2}$ \\ ${ }^{1}$ Department of Marine Science, University of Otago, PO Box 56, Dunedin, New Zealand \\ ${ }^{2}$ Department of Zoology, University of Otago, PO Box 56, Dunedin, New Zealand
}

\begin{abstract}
The 4 dolphin species in the genus Cephalorhynchus have small populations, restricted distributions and are threatened by anthropogenic activities. It is therefore essential that tools be developed for assessing these threats and the effects of management actions. The T-POD is a commercially available acoustic data logger. We evaluated the efficacy of the T-POD for addressing habitat use questions relevant to management by passive acoustic monitoring of Hector's dolphins C. hectori in the Banks Peninsula Marine Mammal Sanctuary (BPMMS), New Zealand. Three T-PODs were deployed at 3 inshore locations in summer and winter over a $2 \mathrm{yr}$ period $(\mathrm{n}=431 \mathrm{~d})$. Acoustic detection data were summarised by detection-positive minutes per day. A linear regression model indicated that season had the largest effect on detection rate $(F=81.95, \mathrm{p}<0.001)$, with T-POD ID (i.e. variation in sensitivity between individual instruments) also having a significant effect $(F=9.45, \mathrm{p}<$ 0.001 ). There was no significant difference between acoustic detection rates at night and during the day (paired $t$-test, $t=0.55, \mathrm{p}=0.59$ ). The present study provides further evidence to support the yearround ban on all gill netting within the BPMMS. We demonstrated that T-PODs can be used to investigate temporal differences in habitat use by Cephalorhynchus dolphins. However, several issues must be considered when designing such experiments; namely the mode of deployment, accounting for variation in sensitivity between individual T-PODs and the possibility of false positive detections from non-target species.
\end{abstract}

KEY WORDS: Cephalorhynchus - T-POD - Acoustic monitoring - Hector's dolphin - Bycatch · Marine protected area

Resale or republication not permitted without written consent of the publisher

\section{INTRODUCTION}

The 4 species of dolphins in the genus Cephalorhynchus are found in cool, temperate waters of the southern hemisphere. All have relatively small population sizes and restricted coastal distributions, making them particularly vulnerable to human impacts (Dawson 2008). Threats include fisheries bycatch (Iñiguez et al. 2003, Dawson \& Slooten 2005), hunting for bait (Lescrauwaet \& Gibbons 1994) and habitat loss due to aquaculture (Ribeiro et al. 2007).

Hector's dolphin Cephalorhynchus hectori is the only member of the genus which has had robust abundance assessments throughout its range (Dawson et al. 2004, Slooten et al. 2004, 2006a) and the species is clas- sified as Endangered (IUCN 2008). Chilean dolphin C. eutropia is classified as Near Threatened while the other 2 species, Commerson's dolphin C. commersonii and Heaviside's dolphin $C$. heavisidii, are listed as Data Deficient (IUCN 2008). The abundance of Hector's dolphin is predicted to continue declining due to bycatch in gill nets (Slooten 2007) and there are concerns that the impacts of fisheries on Chilean and Commerson's dolphins are not sustainable (Iñiguez et al. 2003, Dawson 2008). It is therefore essential that tools be developed for assessing the impacts on Cephalorhynchus dolphins and evaluating the efficacy of management actions.

Static passive acoustic surveys of cetaceans are employed to monitor use of a particular location or 
region and have many potential advantages over visual surveys. They are independent of light levels, less reliant on good weather conditions and can be operated continuously and autonomously for several weeks or months, often at relatively low cost (Mellinger et al. 2007). It is not surprising, therefore, that passive acoustics are now employed in studies of a wide range of cetacean taxa. For baleen whales, whose signals propagate over long distances, large-scale arrays of many hydrophones can be used to monitor extensive areas (e.g. Stafford et al. 1999, Mellinger \& Clark 2003). For odontocetes, whose higher frequency sounds are detectable over much shorter ranges, static acoustic methods are used over small scales to gain information about habitat use (e.g. Koschinski et al. 2003, Wang et al. 2005, Philpott et al. 2007).

The T-POD (Chelonia Ltd.) is a commercially available, battery-powered acoustic data logger which records the occurrence and timing of odontocete echolocation clicks. Following deployment, the data are downloaded to a PC and the accompanying software (TPOD.exe) applies a click train detection algorithm which classifies trains of logged clicks according to how likely they are to be of cetacean origin. T-PODs were designed for studies of habitat use and echolocation behaviour of harbour porpoises Phocoena phocoena (Cox et al. 2001, Koschinski et al. 2003, Carlström 2005, Verfuß et al. 2007). Like harbour porpoises, the vocal repertoire of Cephalorhynchus dolphins consists almost exclusively of ultrasonic, narrow-band echolocation clicks centred around $125 \mathrm{kHz}$ (Kamminga \& Wiersma 1982, Dawson \& Thorpe 1990, Dawson 2008). These sounds have a distinctive click structure with a high signal to noise ratio, making them ideally suited for an automatic detection system (Akamatsu et al. 2001, Verfuß et al. 2007). The TPOD, therefore, seems to be an ideal tool for passive acoustic monitoring of Cephalorhynchus dolphins.

We evaluated the efficacy of the TPOD for addressing habitat use questions relevant to management by passive acoustic monitoring of Hector's dolphins in the Banks Peninsula Marine Mammal Sanctuary (BPMMS), New Zealand. The BPMMS is a marine protected area (MPA) designated in 1988 with the aim of reducing bycatch of Hector's dolphins in gill nets (Dawson \& Slooten 1993). Although Hector's dolphins demonstrate year-round site fidelity at Banks Peninsula (Rayment et al. in press a), there is a seasonal change in distribution, resulting in lower sighting rates inshore in winter (Dawson \& Slooten 1988, Slooten et al. 2006b). A diel trend in distribution has also been reported, with dolphins tending to enter Akaroa Harbour (a large harbour on the south side of Banks Peninsula) early in the day and leave in the afternoon and evening (Stone et al. 1995). If these patterns of distribution are consistent across all inshore habitats around Banks Peninsula, we would expect lower rates of acoustic detection of Hector's dolphins in winter than in summer and at night than during the day. We tested these 2 hypotheses by deploying T-PODs in 3 inshore bay habitats at Banks Peninsula in summer and winter over a period of $2 \mathrm{yr}$.

\section{MATERIALS AND METHODS}

T-POD deployments. T-PODs were deployed at 3 locations at Banks Peninsula (Decanter, Flea and Peraki Bays; Fig. 1) in winter (June to August) and summer (December to February) between June 2004 and February 2006. All 3 locations are relatively narrow bays of similar depth with a sand/silt substrate fringed by rocky wave cut platforms. Three v.3 T-PODs (TPOD identification (ID) nos. 196, 271 and 272) were used throughout the course of the present study. In order to account for varying sensitivity among individual T-PODs (Kyhn et al. 2008), each one was deployed in each location in both seasons. Only one T-POD was deployed in each location at any one time, and the

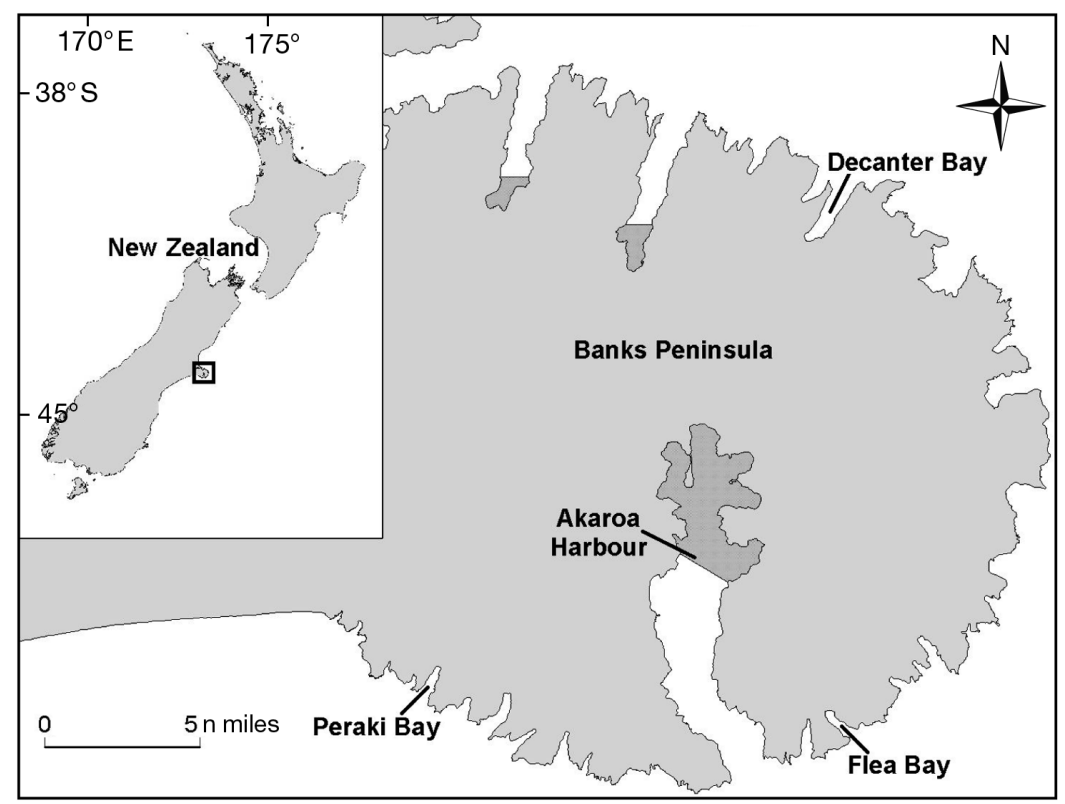

Fig. 1. T-POD deployment locations: Decanter, Flea and Peraki Bays, New Zealand. Dark grey areas are the Banks Peninsula flounder areas where overnight gill netting is permitted between 1 April and 30 September. Inset shows location of Banks Peninsula 
order in which T-PODs were deployed was chosen randomly. The fully balanced experimental design would have resulted in 18 deployments per year with each deployment lasting approximately $20 \mathrm{~d}$. Malfunctions of the T-PODs and constraints on deployment and recovery imposed by the weather resulted in 13 successful deployments in the first year and 18 in the second, yielding 6 to $34 \mathrm{~d}$ (mean $\pm \mathrm{SD}=16.0 \pm 6.7 \mathrm{~d}$ ) of data per deployment.

T-PODs were deployed on temporary moorings consisting of a car tyre filled with concrete. The position of the mooring in each bay was chosen randomly subject to the constraint that it had to be $>500 \mathrm{~m}$ from both the mouth and the head of the bay, and $>100 \mathrm{~m}$ from each side. This was done to maximise the probability of detecting dolphins, while ensuring that detections occurred only from dolphins inside the bay. Previous trials had shown that the maximum detection range with Hector's dolphin was 431 m (Rayment et al. in press b). All subsequent deployments at each site were at the same location. Water depths at these positions ranged from 9.8 to $12.0 \mathrm{~m}$. The T-POD was tied to the mooring block so that it floated vertically in the water column with the transducer approximately $1.5 \mathrm{~m}$ above the seabed. The mooring was marked with a buoy at the water surface.

Hector's dolphin echolocation clicks are strikingly similar to those made by harbour porpoises (for a description of harbour porpoise sounds see Au 1993). For this reason, in all deployments, all 6 scans on the TPOD were set to the default harbour porpoise settings: target (A) filter frequency $=130 \mathrm{kHz}$; reference (B) filter frequency $=90 \mathrm{kHz}$; selectivity (ratio $\mathrm{A}: \mathrm{B})=5$; $\mathrm{A}$ integration period $=$ short $;$ B integration period $=$ long; sensitivity $=4$; limit on clicks logged per scan $=240$. One battery pack (6 D cells) was used in each T-POD, and fresh alkaline batteries were used for each deployment. After recovery, data were downloaded to a PC and click trains were classified by T-POD.exe v.8.11. A previous study with T-PODs and Hector's dolphins (Rayment et al. in press b) showed that detections in the top 2 train categories (Cet Hi and Cet Lo; grouped as Cet All) reliably represented Hector's dolphin echolocation trains, while the 2 lower categories (Doubtful and Very Doubtful) occasionally contained detections originating from boat sonar. Therefore, only detections in the Cet All train categories were used in the analyses. There was little high-frequency noise in wideband recordings made previously in Flea Bay (see Rayment et al. in press b), so masking of Hector's dolphin echolocation signals was not considered to be an issue.

Data analysis. Acoustic detection data were summarised as detection-positive minutes (DPM) per day, i.e. the number of minutes per day which contained $\geq 1$ Hector's dolphin click train. The use of detection-posi- tive time periods (e.g. Mellinger et al. 2004, Verfuß et al. 2007) reduces the potential bias introduced by a small number of highly vocal individuals (Mellinger et al. 2007) and decreases the effect of variation in sensitivity between T-PODs (Dähne et al. 2006).

To assess the effect of season on Hector's dolphin detection, a multiple linear regression model was constructed. Due to rough weather delaying T-POD retrieval during some deployments and occasional issues with T-POD reliability, each site had a different number of monitoring days. For multifactorial designs with unequal replication Zar (1999) recommends the use of multiple regression models. The model accounted for unequal replication per cell by computing the effect tests from the least square means (i.e. estimates of the mean values in a fully balanced design; Langsrud et al. 2007). The dependent variable of the regression model was DPM d $\mathrm{d}^{-1}, \log _{10}$-transformed to satisfy the assumption of normality. The independent variables were Location, Season, Year and T-POD ID. Year was included with 2 levels: Year 1 = winter 2004 and summer 2004-2005, Year 2 = winter 2005 and summer 2005-2006. T-POD ID was included to account for variation in sensitivity among the 3 instruments.

Diel variation in dolphin distribution was investigated by comparing daytime and nighttime rates of detection. All T-POD deployments exceeding $10 \mathrm{~d}$ in duration $(\mathrm{n}=22)$ were divided into periods of daytime and nighttime based on times of sunrise and sunset at Christchurch (Royal Astronomical Society of New Zealand, www.rasnz.org.nz/SRSStimes.htm). For each deployment, the daytime detection rate, $D_{\mathrm{d}}$, was calculated as follows:

$$
D_{\mathrm{d}}=\frac{\mathrm{DPM}_{\mathrm{d}}}{T_{\mathrm{d}}}
$$

where $\mathrm{DPM}_{\mathrm{d}}$ is the total number of DPM during daytime periods and $T_{\mathrm{d}}$ is the total time in hours during daytime periods.

A similar process was used to calculate the nighttime detection rate, $D_{\mathrm{n}}$, for each deployment. The mean of the daytime detection rates was compared with the mean of the nighttime rates by a paired $t$-test.

\section{RESULTS}

The T-POD deployments yielded a total of $431 \mathrm{~d}$ of data, of which 400 (93\%) had detections of Hector's dolphins in the Cet All train categories. DPM d ${ }^{-1}$ ranged from 0 to 429 (mean $\pm \mathrm{SE}=73.6 \pm 3.43$ ). Despite equipment failures and logistical constraints imposed by poor weather, partitioning of deployment days between the different levels of the factors included in the linear regression model was nearly equal (Table 1). 
Table 1. Summary statistics for T-POD deployments. DPM: detection-positive minutes; Year 1，2: see 'Materials and methods'

\begin{tabular}{|lccc|}
\hline Factor & Level & $\mathrm{n}(\mathrm{d})$ & Median DPM d \\
\hline Location & Decanter Bay & 142 & 61 \\
& Flea Bay & 141 & 70 \\
& Peraki Bay & 148 & 39 \\
Season & Summer & 223 & 90 \\
& Winter & 208 & 27 \\
Year & 1 & 201 & 54 \\
& 2 & 230 & 52 \\
T-POD ID & 196 & 143 & 49 \\
& 271 & 148 & 77 \\
& 272 & 140 & 29 \\
\hline
\end{tabular}

There were more than 3 times as many minutes with dolphin detections in summer compared to winter (Table 1, Fig. 2b). In summer, $98 \%$ of deployment days had $\geq 1$ dolphin detection, compared to $88 \%$ in winter. Flea Bay recorded the highest number of dolphin detections per day, followed by Decanter Bay and then Peraki Bay (Fig. 2a). The rate of dolphin detections between years was very similar (Fig. 2c).
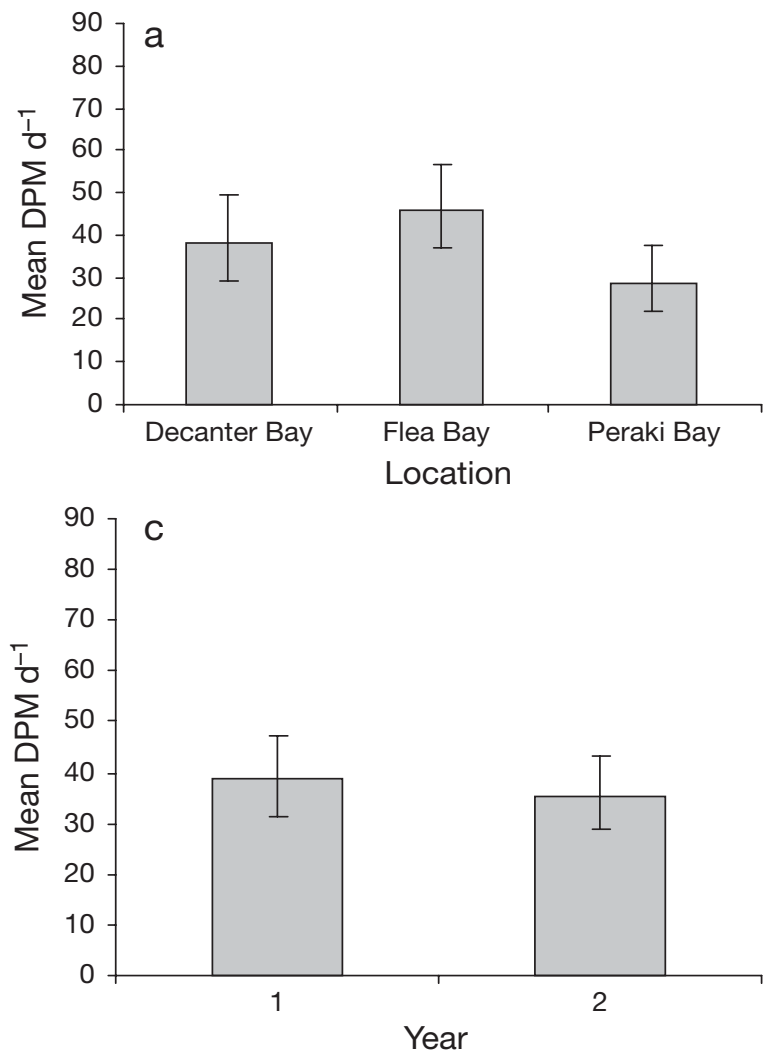

The effect tests from the linear regression model confirmed that there was a very large effect of Season, with that factor alone accounting for more than $76 \%$ of the model sum of squares (Table 2). There was also a significant effect of T-POD ID, showing that there was variation in sensitivity between instruments (Table 2). T-POD 271 was the most sensitive, followed by T-PODs 196 and 272 (Fig. 2d). There were no significant effects of Location or Year, although the pvalue for Location was close to significance. For all factors, the least square means did not differ markedly from the actual means, suggesting that the unequal replication in the present study did not have a large influence on the results.

There was no significant difference in detection rate between night and day (daytime mean $=3.34 \mathrm{DPM} \mathrm{h}^{-1}$,

Table 2. Results of effect tests from the multiple linear regression model. Significant p-values are highlighted in bold

\begin{tabular}{|lcccc|}
\hline Factor & df & SS & $F$ & $p$ \\
\hline Location & 2 & 1.83 & 2.73 & 0.066 \\
Season & 1 & 27.50 & 81.95 & $<\mathbf{0 . 0 0 1}$ \\
Year & 1 & 0.31 & 0.94 & 0.332 \\
T-POD ID & 2 & 6.34 & 9.45 & $<\mathbf{0 . 0 0 1}$ \\
\hline
\end{tabular}
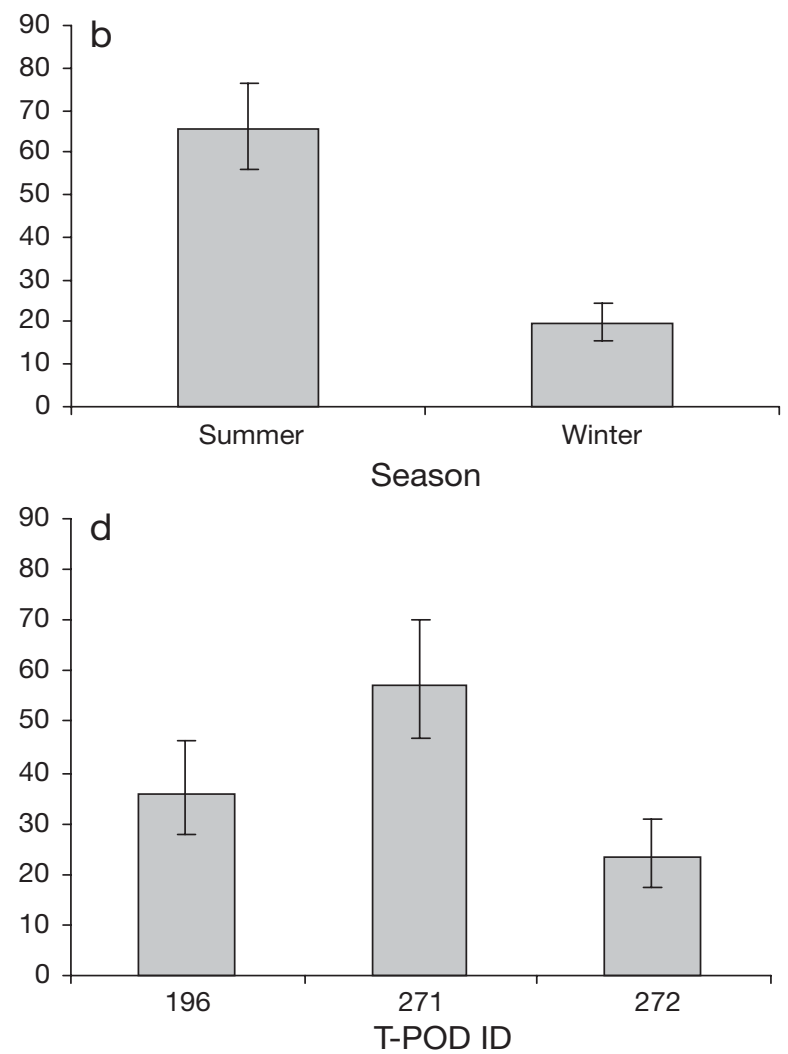

Fig. 2. Variation in mean detection-positive minutes (DPM) per day $( \pm 95 \% \mathrm{CI})$ for factors included in the multiple regression model: (a) Location, (b) Season, (c) Year and (d) T-POD ID. Means and CIs were calculated from the transformed data and then back-transformed for graphical display 
nighttime mean $=3.16 \mathrm{DPM} \mathrm{h}^{-1}, t=0.55, \mathrm{p}=0.59$ ). Daytime rates were similar to nighttime rates in all locations (Fig. 3) and both seasons and years.

\section{DISCUSSION}

The present study showed that T-PODs can be used successfully for continuous acoustic monitoring of Cephalorhynchus dolphins. Multiple locations were monitored simultaneously over a period of $21 \mathrm{mo}$, providing new insights into occurrence and distribution of Hector's dolphins. Individual deployments yielded data for up to $34 \mathrm{~d}$ (this duration could be extended by using 2 battery packs instead of 1). Processing this volume of data was only practical via an automated detection method, which saved time and decreased bias.

Importantly, the acoustic detection data gathered by the T-POD in the present study revealed a seasonal difference in detection rate of Hector's dolphins in inshore habitats. Extrapolation from acoustic detections to statements about dolphin distribution requires the assumption that echolocation rate is relatively constant. There are data from a species with very similar sonar signals suggesting that this assumption is reasonable. Akamatsu et al. (2005) attached miniature stereo acoustic event recorders to finless porpoises Neophocaena phocaenoides via suction cups while the animals swam freely in an oxbow lake. Instrumented porpoises produced echolocation trains frequently, on average every $5.1 \mathrm{~s}$, with no silences longer than $10 \mathrm{~s}$. Furthermore, Verfuß et al. (2007) argued that harbour porpoises use echolocation almost continuously; therefore, differences in acoustic detection rates reflect differences in porpoise density. Carstensen et al. (2006) concluded that echolocation activity of harbour porpoises could be used as a proxy estimate of relative abundance. There is no reason to believe that Hector's dolphins should echolocate less in winter and so we conclude that lower detection rates are likely to reflect lower inshore dolphin densities. This

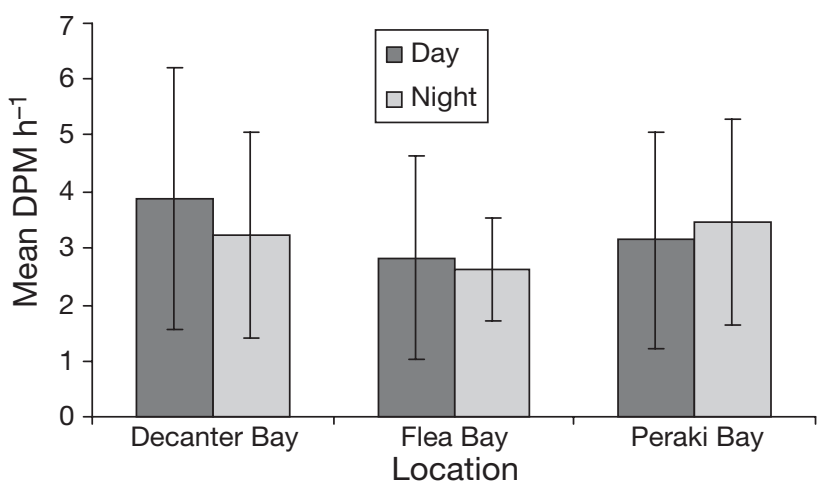

Fig. 3. Mean daytime and nighttime detection rates $( \pm 95 \%$ CI) of Cephalorhynchus dolphins at Decanter, Flea and Peraki Bays, New Zealand. DPM: detection-positive minutes conclusion is supported by results of visual surveys at Banks Peninsula (e.g. Dawson \& Slooten 1988, Slooten et al. 2006b) which show similar seasonal differences. TPODs, therefore, could be employed in studies of localised impacts on Cephalorhynchus species or to evaluate the efficacy of management actions. Indeed, a study using T-PODs in the Baltic Sea demonstrated the impact of the construction of an offshore wind farm on harbour porpoises (Carstensen et al. 2006).

A disadvantage of some acoustic surveys compared to visual surveys is uncertainty over species identification. In studies using T-PODs there is the potential for false positives due to detection of the clicks of non-target cetacean species. Around Banks Peninsula this is highly unlikely as inshore sightings of dolphins other than Hector's dolphins are very rare. For example, during 157 coastal survey trips at Banks Peninsula between June 2004 and February 2006, we made only one sighting of a dolphin species other than Hector's dolphin (W. Rayment unpubl.). In other areas, however, this is likely to be more of a concern. In particular, the ranges of the Cephalorhynchus dolphins overlap with the ranges of dusky dolphin Lagenorhynchus obscurus, Peale's dolphin Lagenorhynchus australis and bottlenose dolphin Tursiops sp. Fortunately, the structure of Cephalorhynchus sonar sounds is quite different from those of the sympatric species (see Au 1993, Au \& Würsig 2004), so careful selection of the T-POD settings should allow discrimination between them. Other T-POD studies (e.g. Philpott et al. 2007) have included at least one scan with settings targeted at detecting other sympatric species to facilitate such discrimination.

In the present study, the variation in sensitivity between T-PODs was accounted for in the experimental design and the analysis. However, the significant effect of T-POD ID emphasises that equality among instruments should not be assumed. Indeed, a study by Kyhn et al. (2008) showed the detection thresholds of 10 individual v.3 T-PODs to be different and that these differences increased over time. The cause of this drift in sensitivity is not well understood. While Kyhn et al. (2008) recommend regular calibration of T-PODs during a study to evaluate the possible effects of detection threshold drift, the fact that we found no effect of year in the present study suggests there was no systematic drift in sensitivity of the T-PODs we used. From v.4 onwards the detection thresholds of individual T-PODs were standardised using a calibrated sound source (Chelonia 2006), resulting in reduced variation in sensitivity (see Dähne et al. 2006).

We deployed our T-PODs on custom-made moorings in relatively sheltered inshore habitats and experienced no loss of or damage to the T-PODs over the course of the study. However, T-PODs do go missing, either due to extreme environmental conditions, acci- 
dents or sabotage. Mooring systems therefore need to be tailored accordingly. Human interference is often the greatest threat and can be minimised by mooring T-PODs to existing structures or using sub-surface floats so they do not attract attention.

\section{Implications of the case study}

The findings of the present study have direct relevance for the management of Hector's dolphin bycatch in gill nets at Banks Peninsula. In winter, detections of Hector's dolphins were made on $88 \%$ of the days that TPODs were deployed, for a median of $27 \mathrm{~min}^{-1}$. These figures are indices of occurrence; they are likely to represent the absolute minimum time that dolphins spent in the vicinity of the T-PODs. Until recently, recreational fishers could legally set gill nets inside the BPMMS in winter (March to October) and therefore there was potential overlap between dolphin distribution and recreational gill netting. On 1 October 2008, new regulations were introduced (Ministry of Fisheries 2008) which banned all gill netting out to 4 nautical miles $(7.4 \mathrm{~km})$ from the coast, except in certain areas of the inner harbours where gill netting for flounders Rhombosolea sp. is permitted (see Fig. 1). However, the fishing industry has objected to these new regulations and the process is currently the subject of a judicial review. The present study provides further evidence to support the year-round ban on all gill netting at Banks Peninsula.

We found no evidence for diel variation in distribution of Hector's dolphins, indicating that the pattern described by Stone et al. (1995) for Akaroa Harbour is not consistent across all the bays of Banks Peninsula. A strength of our acoustic approach is that monitoring occurred during both night and day, and was replicated over 3 bays over 2 yr. Additionally, the 2 methods are based on quite different assumptions. Stone et al.'s (1995) method assumed that the direction of dolphin movement observed from a headland in the early morning and early evening was indicative of density in Akaroa Harbour at night versus during the day. In the present study we draw conclusions about presence/ absence and density of dolphins based on rates of detected vocalisations, assuming that echolocation rate is relatively constant between day and night. This assumption remains to be tested for Hector's dolphins, but appears true for other small cetaceans living in turbid water (e.g. Akamatsu et al. 2005, Verfuß et al. 2007). We therefore believe that the most parsimonious explanation of the results of the present study is that there is no diel difference in distribution of Hector's dolphins at the 3 study bays. The management significance of diel variation in dolphin presence is that within the BPMMS, overnight gill net sets are still per- mitted in the inner harbour flounder areas (see Fig. 1). Our data suggest that this is unsafe for Hector's dolphins. Acoustic monitoring of the Akaroa Harbour flounder area is now being carried out to address this question specifically.

\section{CONCLUSIONS}

The T-POD shows great promise as a tool for passive acoustic monitoring of Cephalorhynchus dolphins. TPODs enable acoustic data on dolphin occurrence to be gathered continuously, allowing temporal changes and spatial differences in habitat use to be investigated, addressing questions that visual surveys cannot. The relatively short distance over which the vocalisations of Cephalorhynchus species are detectable means that acoustic detections can be attributed to a precise area. T-PODs could therefore be used to assess how dolphins respond to localised impacts or management areas. However, several issues need to be addressed in designing such experiments. We recommend the following: (1) T-PODs must be deployed in such a way that they can be reliably and safely recovered; $(2)$ the variation between individual T-PODs must be accounted for in the experimental design or empirically measured, ideally by calibrating each T-POD before and after deployment; (3) knowledge of the echolocation signals of sympatric cetacean species is essential if detections of non-target species are to be distinguished from those of the target species; and (4) investigating the proportion of time that dolphins spend echolocating would substantially strengthen inferences that can be drawn from T-POD data.

Acknowledgements. This project was possible thanks to financial support from the New Zealand Whale and Dolphin Trust, the Whale and Dolphin Conservation Society (UK) and the New Zealand Department of Conservation. Thanks to T. Webster, T. Dearlove, H. Lehmann, J. McKinnell and C. Souter for assistance with fieldwork. Thanks to the Fraser family and Black Cat Group for logistical support and to N. Tregenza (Chelonia) for swift service and answers to T-PODrelated questions. L. Allum, D. Cox and A. Hutt (Department of Conservation) provided assistance with permits required for fieldwork in Flea Bay. The manuscript was improved by comments from 2 anonymous reviewers. W.R. was supported by a University of Otago post-graduate scholarship.

\section{LITERATURE CITED}

Akamatsu T, Wang D, Wang K, Wei Z (2001) Comparison between visual and passive acoustic detection of finless porpoises in the Yangtze River, China. J Acoust Soc Am 109:1723-1727

Akamatsu T, Wang D, Wang K, Naito Y (2005) Biosonar behaviour of free-ranging porpoises. Proc R Soc Lond B Biol Sci 272:797-801 
Au WWL (1993) The sonar of dolphins. Springer-Verlag, New York

Au WWL, Würsig B (2004) Echolocation signals of dusky dolphins (Lagenorhynchus obscurus) in Kaikoura, New Zealand. J Acoust Soc Am 115:2307-2313

Carlström J (2005) Diel variation in echolocation behaviour of wild harbour porpoises. Mar Mamm Sci 21:1-12

Carstensen J, Henriksen OD, Teilman J (2006) Impacts of offshore wind farm construction on harbour porpoises: acoustic monitoring of echolocation activity using porpoise detectors (T-PODs). Mar Ecol Prog Ser 321:295-308

Chelonia (2006) T-POD help file. Available at www.chelonia.co.uk/tpod_downloads.htm

Cox TM, Read AJ, Solow A, Tregenza N (2001) Will harbour porpoises (Phocoena phocoena) habituate to pingers? J Cetacean Res Manag 3:81-86

Dähne M, Verfuß UK, Diederichs A, Meding A, Benke H (2006) T-POD test tank calibration and field calibration. In: Leeney RH, Tregenza NJC Proc Workshop Static Acoustic Monitoring of Cetaceans, 20th Annual Meeting of the European Cetacean Society, Gdynia, Poland 2 April 2006. European Cetacean Society. www.seaturtle.org/mtrg/ personnel/SAM_report_ECS_2006.pdf

Dawson SM (2008) Cephalorhynchus dolphins (C. heavisidii, C. eutropa, C. hectori, and C. commerssonii). In: Perrin WF, Würsig B, Thewissen JGM (eds) Encyclopedia of marine mammals, 2nd edn. Academic Press, San Diego, CA, p 191-195

Dawson SM, Slooten E (1988) Hector's dolphin Cephalorhynchus hectori: distribution and abundance. Rep Int Whal Comm (Spec Issue) 9:315-324

$>$ Dawson SM, Slooten E (1993) Conservation of Hector's dolphins: the case and process which led to the establishment of the Banks Peninsula Marine Mammal Sanctuary. Aquat Conserv 3:207-221

Dawson SM, Slooten E (2005) Management of gillnet bycatch of cetaceans in New Zealand. J Cetacean Res Manag 7:59-64

Dawson SM, Thorpe CW (1990) A quantitative analysis of the sounds of Hector's dolphin. Ethology 86:131-145

Dawson SM, Slooten E, DuFresne SD, Wade P, Clement DM (2004) Small-boat surveys for coastal dolphins: line-transect surveys of Hector's dolphins (Cephalorhynchus hectori). Fish Bull 102:441-451

Iñiguez MA, Hevia M, Gasparrou C, Tomsin AL, Secchi ER (2003) Preliminary estimate of incidental mortality of Commerson's dolphins (Cephalorhynchus commersonii) in an artisanal setnet fishery in Angelina Beach and Ria Gallegos, Santa Cruz, Argentina. Lat Am J Aquat Mamm 2:87-94

IUCN (2008) 2008 IUCN Red List of Threatened Species. Available at www.iucnredlist.org

Kamminga C, Wiersma H (1982) Investigations on cetacean sonar. V. The true nature of the sonar sound of Cephalorhynchus commersonii. Aquat Mamm 9:95-104

Koschinski S, Culik BM, Henriksen OD, Tregenza N, Ellis G, Jansen C, Kathe G (2003) Behavioural reactions of freeranging porpoises and seals to the noise of a simulated 2 MW windpower generator. Mar Ecol Prog Ser 265: 263-273

Kyhn LA, Tougaard J, Teilmann J, Wahlberg M, Jørgensen PB, Bech NI (2008) Harbour porpoise (Phocoena phocoena) static acoustic monitoring: laboratory detection thresholds of T-PODs are reflected in field sensitivity. J Mar Biol Assoc UK 88:1085-1091

Langsrud O, Jorgensen K, Ofstad R, Naes T (2007) Analyzing designed experiments with multiple responses. J Appl Stat 34:1275-1296
Lescrauwaet AK, Gibbons J (1994) Mortality of small cetaceans and the crab bait fishery in the Magallanes area of Chile since 1980. Rep Int Whal Comm (Spec Issue) 15:485-494

> Mellinger DK, Clark CW (2003) Blue whale (Balaenoptera musculus) sounds in the North Atlantic. J Acoust Soc Am 114:1108-1119

Mellinger DK, Stafford KM, Fox CG (2004) Seasonal occurrence of sperm whale (Physeter macrocephalus) sounds in the Gulf of Alaska, 1999-2001. Mar Mamm Sci 20: $48-62$

Mellinger DK, Stafford KM, Moore SE, Dziak RP, Matsumoto $\mathrm{H}$ (2007) An overview of fixed passive acoustic observation methods for cetaceans. Oceanography 20:36-45

Ministry of Fisheries (2008) Minister announces new measures to protect dolphins. Available at www.fish.govt. nz/en-nz/Press/Press+Releases+2008/ May08/hector.htm

Philpott E, Englund A, Ingram S, Rogan E (2007) Using TPODs to investigate the echolocation of coastal bottlenose dolphins. J Mar Biol Assoc UK 87:11-17

Rayment W, Dawson S, Slooten E, Bräger S, Du Fresne S, Webster $\mathrm{T}$ (in press a) Kernel density estimates of alongshore home range of Hector's dolphins at Banks Peninsula, New Zealand. Mar Mamm Sci

Rayment W, Dawson S, Slooten E (in press b) Trialling the TPOD with Hector's dolphins. J Mar Biol Assoc UK

> Ribeiro S, Viddi FA, Cordeiro JL, Freitas TRO (2007) Fine scale habitat selection of Chilean dolphins (Cephalorhynchus eutropia): interactions with aquaculture activities in southern Chiloe Island, Chile. J Mar Biol Assoc UK 87:119-128

Slooten E (2007) Conservation management in the face of uncertainty: effectiveness of four options for managing Hector's dolphin bycatch. Endang Species Res 3: 169-179

Slooten E, Dawson SM, Rayment WJ (2004) Aerial surveys for coastal dolphins: abundance of Hector's dolphins off the South Island west coast, New Zealand. Mar Mamm Sci 20:477-490

Slooten E, Dawson SM, Rayment W, Childerhouse S (2006a) A new abundance estimate for Maui's dolphin: What does it mean for managing this critically endangered species? Biol Conserv 128:576-581

Slooten E, Rayment W, Dawson S (2006b) Offshore distribution of Hector's dolphin at Banks Peninsula: Is the Banks Peninsula Marine Mammal Sanctuary large enough? N Z J Mar Freshw Res 40:333-343

> Stafford KM, Nieukirk SL, Fox CG (1999) Low frequency whale sounds recorded on hydrophones moored in the eastern tropical Pacific Ocean. J Acoust Soc Am 106: 3687-3698

Stone GS, Brown J, Yoshinaga A (1995) Diurnal movement patterns of Hector's dolphin as observed from clifftops. Mar Mamm Sci 11:395-402

- Verfuß UK, Honnef CG, Meding A, Dahne M, Mundry R, Benke H (2007) Geographical and seasonal variation of harbour porpoise (Phocoena phocoena) presence in the German Baltic Sea revealed by passive acoustic monitoring. J Mar Biol Assoc UK 87:165-176

Wang K, Wang D, Akamatsu T, Li S, Xiao J (2005) A passive acoustic monitoring method applied to observation and group size estimation of finless porpoises. J Acoust Soc Am 118:1180-1185

Zar JH (1999) Biostatistical analysis, 4th edn. Prentice Hall, Upper Saddle River, NJ 